\title{
Recent advances in the management of hypertension
}

\section{José Antonio García-Donaire and Luis M Ruilope*}

\author{
Address: Hypertension Unit, Hospital 12 de Octubre, 28041 Madrid, Spain \\ * Corresponding author: Luis M Ruilope (ruilope@ad-hocbox.com) \\ Fl000 Medicine Reports 2010, 2:19 (doi:10.3410/M2-19)
}

The electronic version of this article is the complete one and can be found at: http://fl000.com/reports/medicine/content/2/19

\begin{abstract}
Recently, there have been several reports related to the adequacy of blood pressure (BP) control in high-risk hypertensive patients. These aspects have been reviewed in the recently published reappraisal of the European Society of Hypertension guidelines, and this short review comments on and briefly extends the discussion of this situation. In summary, a low BP goal when cardiorenal disease is advanced can be risky. However, attaining normal BP levels at earlier stages in the cardiorenal continuum is probably totally adequate.
\end{abstract}

\section{Introduction and context}

The latest evidence supported by the most recent comparative trials [1-6] has prompted a reconsideration of the current guidelines for the management of hypertension [7]. Consensus over the initiation of antihypertensive treatment and blood pressure (BP) goals is essential in order to optimize hypertension management and outcomes. In addition, BP measurement methods must be tested in order to establish the optimal and most reliable approach for determining accurate BP levels. Current recommendations are based on the finding that a given difference in $\mathrm{BP}$, as measured in the clinic, results in a given difference in outcome, as demonstrated by observational and interventional studies and their meta-analyses [8-10].

\section{Recent advances}

Guidelines recommend the use of antihypertensive drugs in patients with grade 1 hypertension at low or moderate cardiovascular (CV) risk - namely, when systolic BP (SBP) is between 140 and $159 \mathrm{~mm} \mathrm{Hg}$ or when diastolic $\mathrm{BP}$ is between 90 and $99 \mathrm{~mm} \mathrm{Hg}$ (or when both occur) provided that non-pharmacological treatment has proven ineffective. Nevertheless, there is inconclusive evidence of whether older persons with grade 1 hypertension, diabetics, or patients with coronary disease and high normal BP should be treated [7]. Therefore, ongoing and future trials are necessary to set up a more robust assessment of treatment benefits in these patients (Table 1). Also, discussion about the most adequate BP goals is emerging from a number of recent studies. It seems reasonable, particularly given the results of a number of prospective trials, that SBP should be reduced to less than $140 \mathrm{~mm} \mathrm{Hg}$ in the general population of patients with grade 1 or 2 hypertension and low or moderate total CV risk. Information on BP thresholds and targets for drug treatment has also resulted from post hoc analyses of event-based trials and from studies on the effects of treatment on organ damage of prognostic importance, although, admittedly, this is weaker evidence. In the ONgoing Telmisartan Alone and in combination with Ramipril Global Endpoint Trial (ONTARGET) [3], favorable effects of BP reductions were seen when initial SBP values were above $140 \mathrm{~mm} \mathrm{Hg}$, even after adjusting for potential confounders, and a greater BP reduction was usually accompanied by greater $\mathrm{CV}$ protection. Conversely, the benefit was less obvious and primarily limited to stroke patients in whom initial SBP was in the range of $130 \mathrm{~mm} \mathrm{Hg}$ [11]. The lack of benefit observed in this trial was directly related to the high CV risk of the population included. Consequently, the recommendation of previous guidelines to aim for a lower SBP goal $(<130 \mathrm{~mm} \mathrm{Hg})$ in patients at very high CV risk may be prudent but is not consistently supported by trial evidence. In no randomized trial in diabetic patients has SBP been reduced to below $130 \mathrm{~mm} \mathrm{Hg}$ with 


\section{Table I. Consensus in treatment initiation [7]}

I. Although trial evidence is scanty, it appears reasonable to recommend that, in grade I hypertensives (systolic blood pressure [SBP] of I40-I59 $\mathrm{mm} \mathrm{Hg}$ or diastolic blood pressure [DPB] of $90-99 \mathrm{~mm} \mathrm{Hg}$ ) at low or moderate risk, drug therapy should be started after a suitable period with lifestyle changes. A more prompt initiation of treatment is advisable if grade I hypertension is associated with a high level of risk or if hypertension is grade 2 or 3. 2. In patients with high normal blood pressure (BP) (SBP of I30-139 mm Hg or DPB of $85-89 \mathrm{~mm} \mathrm{Hg}$ ) uncomplicated by diabetes or previous cardiovascular events, no trial evidence of treatment benefits, except for a delayed onset of hypertension (crossing the $140 / 90 \mathrm{~mm} \mathrm{Hg}$ cutoff) is available.

3. Initiation of antihypertensive drug therapy in diabetic patients with high normal BP is currently unsupported by prospective trial evidence. For the time being, it appears prudent to recommend treatment initiation in high normal BP diabetic patients if subclinical organ damage (particularly microalbuminuria or proteinuria) is present.

4. Trial evidence concerning antihypertensive drug treatment in patients with previous cardiovascular events in the absence of hypertension is controversial, and further trials must be completed before firm recommendations can be given.

5. Early BP-lowering treatment, before organ damage develops or becomes irreversible or cardiovascular events occur, appears to be a prudent recommendation.

\section{Table 2. Consensus in blood pressure goals of treatment [7]}

I. On the whole, there is sufficient evidence to recommend that systolic blood pressure (SBP) be lowered to below $140 \mathrm{~mm} \mathrm{Hg}$ (and diastolic blood pressure [DBP] to below $90 \mathrm{~mm} \mathrm{Hg}$ ) in all hypertensive patients, both those at low moderate risk and those at high risk. Evidence is missing only in older hypertensive patients, in whom the benefit of lowering SBP to below $140 \mathrm{~mm} \mathrm{Hg}$ has never been tested in randomized trials.

2. The recommendation of previous guidelines to aim for a lower SBP goal $(<130 \mathrm{~mm} \mathrm{Hg})$ in diabetic patients and in patients at very high cardiovascular risk (previous cardiovascular events) may be wise, but it is not consistently supported by trial evidence. In no randomized trial in diabetic patients has SBP been reduced to below $130 \mathrm{~mm} \mathrm{Hg}$ with proven benefits, and trials in which SBP was lowered to below $130 \mathrm{~mm} \mathrm{Hg}$ in patients with previous cardiovascular events have produced controversial results.

3. Despite their obvious limitations and a lower strength of evidence, post hoc analyses of trial data indicate a progressive reduction of incidence of cardiovascular events with progressive lowering of SBP to about $120 \mathrm{~mm} \mathrm{Hg}$ and DBP to about $75 \mathrm{~mm} \mathrm{Hg}$, although the additional benefit at low BP values becomes rather small. A J-curve phenomenon is unlikely to occur until lower values are reached, except perhaps in patients with advanced atherosclerotic artery diseases.

4. On the basis of current data, it may be prudent to recommend lowering SBP/DBP to values within the range of I30- I39/80 to $85 \mathrm{~mm} \mathrm{Hg}$ (in particular, to lower values in this range) in all hypertensive patients. However, additional critical evidence from specific randomized trials is desirable.

proven benefits, and trials in which SBP was lowered to below $130 \mathrm{~mm} \mathrm{Hg}$ in patients with previous $\mathrm{CV}$ events have produced controversial results (Table 2).

Finally, a close analysis of most of the relevant trials suggests that the absence of benefit of antihypertensive therapy in some trials might be due to the fact that some patients have normal $\mathrm{BP}$ at trial entry. Enrollment of patients into clinical trials on the basis of office-based BP alone might no longer be appropriate. An increasing amount of data is coming from clinical trials that include patients who are evaluated by ambulatory monitoring of BP [12-14]. The results of these studies may allow a better assessment of trial eligibility. Moreover, they identify the individuals with the lowest actual BP, who thus are at higher risk of adverse effects of treatment.

\section{Implications for clinical practice}

The question of whether trials should include ambulatory $\mathrm{BP}$ monitoring and home $\mathrm{BP}$ monitoring as well as conventional clinic measurements must be answered in upcoming trials. Ambulatory BP values are known to correlate with organ damage and CV events better than clinic measurement does [15]. However, ambulatory BP monitoring is not widely employed in trials, and when it is employed, it is in a minor subgroup of patients only. So far, when ambulatory BP was measured, the correlation between the antihypertensive effect measured by ambulatory and office BP appears to be quite different. The proportion of hypertensive patients achieving satisfactory BP control also differs depending on whether $\mathrm{BP}$ is measured in the clinic or by ambulatory monitoring. Comparative data are few and show discrepant results: some controlled studies indicate an easier BP control by clinic measurement $(<140 / 90 \mathrm{~mm} \mathrm{Hg})$ than by ambulatory BP monitoring ( $<130 / 80 \mathrm{~mm} \mathrm{Hg})$ [16], whereas Spanish registry data $[12,17]$ suggest that almost half of all patients with office-diagnosed hypertension are normotensive when assessed by ambulatory BP monitoring. Hence, future trials should use ambulatory $\mathrm{BP}$ monitoring alongside conventional clinic BP measurements.

\section{Abbreviations}

$\mathrm{BP}$, blood pressure; CV, cardiovascular; SBP, systolic blood pressure.

\section{Competing interests}

The authors declare that they have no competing interests.

\section{References}

I. Patel A; ADVANCE Collaborative Group, MacMahon S, Chalmers J, Neal B, Woodward M, Billot L, Harrap S, Poulter N, Marre M, Cooper M, Glasziou P, Grobbee DE, Hamet P, Heller S, Liu LS, Mancia G, Mogensen CE, Pan CY, Rodgers A, Williams B: Effects of a fixed combination of perindopril and indapamide on 
macrovascular and microvascular outcomes in patients with type 2 diabetes mellitus (the ADVANCE trial): a randomised controlled trial. Lancet 2007, 370:829-40.

FI000 Factor 3.2 Recommended

Evaluated by Phyllis August 29 Nov 2007, Jerome Fleg 13 Dec 2007

2. Jamerson K, Weber MA, Bakris GL, Dahlöf B, Pitt B, Shi V, Hester A, Gupte J, Gatlin M, Velazquez EJ; ACCOMPLISH Trial Investigators: Benazepril plus amlodipine or hydrochlorothiazide for hypertension in high-risk patients. N Engl J Med 2008, 359:24I7-28.

FI000 Factor 6.0 Must Read

Evaluated by Raymond Townsend 07 Jan 2009

3. ONTARGET Investigators, Yusuf S, Teo KK, Pogue J, Dyal L, Copland I, Schumacher H, Dagenais G, Sleight P, Anderson C: Telmisartan, ramipril, or both in patients at high risk for vascular events. N Engl J Med 2008, 358:1547-59.

FI000 Factor 10.0 Exceptional

Evaluated by Csaba Kovesdy 15 Apr 2008, Sripal Bangalore 23 Apr 2008, Enyu Imai 06 May 2008, Ernie Esquivel 14 May 2008

4. Telmisartan Randomised AssessmeNt Study in ACE iNtolerant subjects with cardiovascular Disease (TRANSCEND) Investigators, Yusuf S, Teo K, Anderson C, Pogue J, Dyal L, Copland I, Schumacher H, Dagenais G, Sleight P: Effects of the angiotensinreceptor blocker telmisartan on cardiovascular events in high-risk patients intolerant to angiotensin-converting enzyme inhibitors: a randomised controlled trial. Lancet 2008, 372: I 174-83.

5. Yusuf S, Diener HC, Sacco RL, Cotton D, Ounpuu S, Lawton WA, Palesch Y, Martin RH, Albers GW, Bath P, Bornstein N, Chan BP, Chen ST, Cunha L, Dahlöf B, De Keyser J, Donnan GA, Estol C, Gorelick P, Gu V, Hermansson K, Hilbrich L, Kaste M, Lu C, Machnig T, Pais P, Roberts R, Skvortsova V, Teal P, Toni D, et al.: Telmisartan to prevent recurrent stroke and cardiovascular events. N Engl J Med 2008, 359: I225-37.

6. Beckett NS, Peters R, Fletcher AE, Staessen JA, Liu L, Dumitrascu D, Stoyanovsky V, Antikainen RL, Nikitin Y, Anderson C, Belhani A, Forette F, Rajkumar C, Thijs L, Banya W, Bulpitt C]; HYVET Study Group: Treatment of hypertension in patients 80 years of age or older. N Engl J Med 2008, 358:1887-98.

Changes Clinical Practice

FI000 Factor 10.7 Exceptional

Evaluated by Deepak Bhatt I4 Apr 2008, Ramachandran S Vasan 15 Apr 2008, Jerome Fleg 18 Apr 2008, Annemarie Hennessy 29 Apr 2008, Ernesto Schiffrin 02 May 2008, Wilbert Aronow 07 May 2008, Kazuomi Kario 03 Jun 2008

7. Mancia G, Laurent S, Agabiti-Rosei E, Ambrosioni E, Burnier M, Caulfield MJ, Cifkova R, Clément D, Coca A, Dominiczak A, Erdine S, Fagard R, Farsang C, Grassi G, Haller H, Heagerty A, Kjeldsen SE, Kiowski W, Mallion JM, Manolis A, Narkiewicz K, Nilsson P, Olsen MH, Rahn KH, Redon J, Rodicio J, Ruilope L, Schmieder RE, Struijker-Boudier HA, Van Zwieten PA, et al.: Reappraisal of European guidelines on hypertension management: a
European Society of Hypertension Task Force document. Blood Press 2009, 18:308-47.

8. Prospective Studies Collaboration: Age-specific relevance of usual blood pressure to vascular mortality: a meta-analysis of individual data for one million adults in 61 prospective studies. Lancet 2002, 360:1903-13.

9. Blood Pressure Lowering Treatment Trialists' Collaboration: Effects of different blood-pressure-lowering regimens on major cardiovascular events: results of prospectively designed overviews of randomised trials. Lancet 2003, 362: 1527-35.

10. Collins R, Peto R, MacMahon S, Hebert P, Fiebach NH, Eberlein KA, Godwin J, Qizilbash N, Taylor JO, Hennekens CH: Blood pressure, stroke, and coronary heart disease. Part 2: short-term reductions in blood pressure: overview of randomised drug trials in their epidemiological context. Lancet 1990, 335:827-38.

II. Sleight P, Redon J, Verdecchia P, Mancia G, Gao P, Fagard R, Schumacher H, Weber M, Böhm M, Williams B, Pogue J, Koon T, Yusuf S; ONTARGET investigators: Prognostic value of blood pressure in patients with high vascular risk in the Ongoing Telmisartan Alone and in combination with Ramipril Global Endpoint Trial study. J Hypertens 2009, 27:1360-9.

12. Banegas JR, Messerli FH, Waeber B, Rodríguez-Artalejo F, de la Sierra A, Segura J, Roca-Cusachs A, Aranda P, Ruilope LM: Discrepancies between office and ambulatory blood pressure: clinical implications. Am J Med 2009, I22: | |36-4|.

13. Banegas JR, Segura J, de la Sierra A, Gorostidi M, Rodríguez-Artalejo F, Sobrino J, de la Cruz JJ, Vinyoles E, del Rey RH, Graciani A, Ruilope LM; Spanish Society of Hypertension ABPM Registry Investigators: Gender differences in office and ambulatory control of hypertension. Am J Med 2008, I 2 I: 1078-84.

14. de la Sierra A, Redon J, Banegas JR, Segura J, Parati G, Gorostidi M, de la Cruz JJ, Sobrino J, Llisterri JL, Alonso J, Vinyoles E, Pallarés V, Sarría A, Aranda P, Ruilope LM; Spanish Society of Hypertension Ambulatory Blood Pressure Monitoring Registry Investigators: Prevalence and factors associated with circadian blood pressure patterns in hypertensive patients. Hypertension 2009, 53:466-72.

15. Mancia G, De Backer G, Dominiczak A, Cifkova R, Fagard R, Germano G, Grassi G, Heagerty AM, Kjeldsen SE, Laurent S, Narkiewicz K, Ruilope L, Rynkiewicz A, Schmieder RE, Boudier HA, Zanchetti A, Vahanian A, Camm J, De Caterina R, Dean V, Dickstein K, Filippatos G, Funck-Brentano C, Hellemans I, Kristensen SD, McGregor K, Sechtem U, Silber S, Tendera M, Widimsky $P$, et al.: 2007 Guidelines for the Management of Arterial Hypertension: The Task Force for the Management of Arterial Hypertension of the European Society of Hypertension (ESH) and of the European Society of Cardiology (ESC). J Hypertens 2007, 25: I I05-87.

16. Mancia G, Parati G: Office compared with ambulatory blood pressure in assessing response to antihypertensive treatment: a meta-analysis. J Hypertens 2004, 22:435-45.

17. Banegas JR, Segura J, Sobrino J, Rodríguez-Artalejo F, de la Sierra A, de la Cruz JI, Gorostidi M, Sarría A, Ruilope LM; Spanish Society of Hypertension Ambulatory Blood Pressure Monitoring Registry Investigators: Effectiveness of blood pressure control outside the medical setting. Hypertension 2007, 49:62-8. 